\title{
Chapter 1. David Sissons and D Special Section
}

\author{
Desmond Ball
}

During the Second World War, Australia hosted three organisations concerned with the cryptanalysis of intercepted Japanese radio communications. The activities of two of these, respectively concerned with Imperial Japanese Navy (IJN) signals and Japanese army and air force signals, have been widely described and discussed by historians and veterans since the 1970s. ${ }^{1}$

This volume, which has been produced primarily as a result of painstaking efforts by David Sissons, provides a comprehensive and authoritative account of the third, Diplomatic Special Section (D Special Section) of the Australian Military Forces HQ in Melbourne, which was responsible for cryptographic activities concerning Japanese diplomatic communications. D Special Section and its activities remained a closely guarded secret for 20 years after the navy and army stories became public. The Australian Government consistently refused to admit that it ever intercepted diplomatic communications, even in wartime. After all, it was and still is a signatory to Vienna and Geneva conventions on diplomatic relations under which the host country must permit and protect free communication between the diplomats of the mission and their home country'. Fortunately, the US cryptological authorities have been much less sanctimonious.

The Royal Australian Navy's (RAN) involvement in signals intelligence (SIGINT) activities began in 1940 when two high frequency (HF) radio interception and direction-finding (HF DF) stations became operational, located at HMAS Coonawarra near Darwin and HMAS Harman outside Canberra. These stations operated as part of the Royal Navy (RN) component of the Far East Combined Bureau (FECB), then based in Singapore and itself a component of Britain's SIGINT organisation, the Government Code \& Cypher School (GC\&CS). Paymaster-Commander Eric Nave, RN, set up a small cryptanalytic organisation in Melbourne, which analysed Japanese naval traffic from the Mandated Islands and Japanese commercial shipping traffic that was collected at Coonawarra and Harman, as well as some Japanese diplomatic traffic. In early 1942, the US navy's SIGINT unit, codenamed Cast, was evacuated in three tranches from the Philippines to Melbourne. It was established there on the middle floor of the

1 Desmond Ball and David Horner, Breaking the Codes: Australia's KGB Network, 1944-1950 (Sydney: Allen \& Unwin, 1998), chapter 4. 
heavily guarded Monterey flats in Queens Road, South Yarra, near Albert Park. Soon formally known as FRUMEL (Fleet Radio Unit, Melbourne), it effectively subsumed the RAN's SIGINT organisation.

The Australian army's SIGINT organisation was the Australian Special Wireless Group (ASWG), which established intercept stations at Coomalie Creek, about 80 kilometres south of Darwin and initially maintained by the 51st Special Wireless Section; Kalinga near Brisbane, maintained by the 53rd Special Wireless Section and, from May 1943, the HQ of the ASWG; and, Mornington, south of Melbourne, maintained by the 52nd Special Wireless Section. Elements of the 55th Section moved to New Guinea in July 1942. Soon after General Douglas MacArthur arrived in Melbourne, it had been agreed to form a combined Allied organisation called Central Bureau. It was established on 15 April 1942 in a large house, Cranleigh, at 225 Domain Road in South Yarra and moved to Brisbane in September 1942. The bureau was responsible for cryptanalysis of Japanese army and Japanese army air force signals, with material collected by both US army and ASWG stations.

Both the RAN and the army began fledgling activities with respect to Japanese diplomatic communications before Japan attacked Pearl Harbor in December 1941. In the case of the navy, Nave's Special Intelligence Bureau (SIB) had worked on diplomatic cyphers through 1940-41. In the case of the army, in early 1940 the Military Intelligence staff at Eastern Command in Sydney formed a small group of mathematicians and classicists from Sydney University to practise codebreaking on Japanese consular traffic. In 1941 the group succeeded in breaking the Japanese LA code, a low-grade consular code. In early 1940 a Diplomatic and Press Section was formed in Melbourne, with an intercept station at Park Orchards that was maintained by the army's 5th Special Wireless Section. In mid-1941 several members of the Sydney University group were called up and posted to Nave's SIB; the first of these was Dr Athanasius P. Treweek. Others, including Professor Arthur Dale Trendall, joined it soon after the outbreak of the Pacific war. ${ }^{2}$ When FRUMEL began operations, the SIB joined it in the Monterey Building. The uniformed members went to the middle floor to work on Japanese naval traffic and the civilian members moved to a one-bedroom flat on the top floor to concentrate on diplomatic traffic.

In November 1942, the diplomatic group was transferred from RAN control to the army, moved to the second floor of 'A' Block in Victoria Barracks, and named D Special Section. From January 1942, until his return to Sydney in June 1944,

2 Peter Donovan and John Mack, 'Sydney University, T.G. Room and Codebreaking in WWII', part 1, Australian Mathematical Society Gazette, vol. 29, no. 2, 2002; and Peter Donovan and John Mack, 'Sydney University, T.G. Room and Codebreaking in WWII', part 2, Australian Mathematical Society Gazette, vol. 29, no. 3, 2002 . 
the section was headed by Trendall, Professor of Greek at Sydney University. ${ }^{3}$ Intercepts were initially obtained by the station at Park Orchards. In April 1942 a station was established at Ferny Creek, in the Dandenong Ranges, specifically to intercept Japanese diplomatic traffic for Trendall's section. In August the station was moved to Bonegilla, near Albury-Wodonga, where the 52nd Special Wireless Section was formed. It was staffed mainly by women of the Australian Women's Army Service (AWAS). It moved to Mornington in November 1943.

\section{David Sissons}

Sissons matriculated in 1942 from Scotch College in Melbourne, where he was dux in Latin and also received high marks in mathematics. He entered Melbourne University, where he planned to major in Classics, at the beginning of 1943. At the end of his first year, however, following his 18th birthday on 21 December 1943, he was called up for active service and 'marched in' for fulltime duty on 27 June 1944. He spent eight weeks at a recruit training camp at Cowra in western New South Wales, not far from a Japanese prisoner of war camp near the town. Sissons was there on 5 August when the Japanese prisoners attempted a mass breakout; during the escape and subsequent recapture of the POWs, four Australian soldiers and 231 Japanese soldiers died and 108 prisoners were wounded. Sissons was among the young recruits who were employed in rounding up the escapees and he went on to receive seven months Japanese language training. He was posted to D Special Section as a linguist/translator in April 1945, where he worked until September 1945.

In 1978, my colleague David Horner and I published articles on Australia and Allied SIGINT during the Second World War in which we noted the existence of a unit concerned with cryptanalysis of Japanese diplomatic traffic. ${ }^{4}$ I had found a reference in US Congressional testimony on the Pearl Harbor attack in December 1941, published in 1946, which stated that: 'The Australians had a small Communications Intelligence Organization and in December 1941 they were intercepting Japanese diplomatic radio traffic and reading messages in the J-19 system'. ${ }^{5}$ It also noted that the interception stations in Australia often picked up transmissions that 'skipped over' other US and British intercept stations in Southeast Asia, 'particularly if the Japanese were using frequencies optimised for communications with their Embassies in Washington, Rio and

3 R.S. Merrillees, 'Professor A.D. Trendall and his Band of Classical Cryptographers', Working Paper No. 355, Strategic and Defence Studies Centre, The Australian National University, Canberra, January 2001. 4 Desmond J. Ball, 'Allied Intelligence Cooperation Involving Australia During World War II', Australian Outlook, vol. 32, no. 3, December 1978, pp. 299-309; and, D.M. Horner, 'Special Intelligence in the SouthWest Pacific Area in World War II', Australian Outlook, vol. 32, no. 3, December 1978, pp. 310-27.

5 US Congress, Hearings before the Joint Committee on the Investigation of the Pearl Harbor Attack, Pearl Harbor Attack (Washington, D.C.: US Government Printing Office, 1946), part 8, p. 3614. 
Buenos Aires' ${ }^{6}$ Sissons was excited about our revelation, and was energised to compile as much information as he could about the history and activities of his former unit.

He assembled everything he could find on the public record, including relevant records held by the National Archives of Australia and the Australian War Memorial (AWM) in Canberra. Somewhat disappointed with his scant and fragmented findings, he decided to enlist the assistance of others who had been involved in one way or another with D Special Section, and Japanese diplomatic traffic more generally.

Fittingly, he began with Alan Stripp, a famous wartime cryptanalyst who had worked on Japanese cyphers at both the GC\&CS HQ at Bletchley Park and one of its major 'outstations' in Delhi in India. He published a detailed account of 'breaking Japanese codes' in October 1987 and, in late 1988, had just completed a book on this subject which included a survey of the codes and cyphers used by the Japanese, including several systems used for diplomatic traffic (such as J-19, PURPLE and Greater East Asian Ministry (GEAM)). ${ }^{7}$ In a long letter to Stripp in 1988, Sissons explained what he knew at that time about the interception of Japanese diplomatic traffic in Australia. He attached to this letter a page from the war diary of the 52nd Special Wireless Section categorising the 4,457 Japanese diplomatic messages that had been intercepted at Bonegilla in March 1943, and five pages from the war diary summarising the 3,348 intercepts taken at Mornington from 1 to 31 May 1944, which he had found in the AWM. This letter and the attachments are reproduced as the beginning entry in the Annexes to this volume. (See Annex 1)

In the early 1990s Sissons initiated correspondence with several of his former colleagues from D Special Section. His letters were extremely detailed and meticulous, sometimes amounting to several thousand words, often with annexes. In his inimitable way, he usually followed up with further questions to clarify names, events, dates or other details. His principal interlocutors were Ronald Bond, Ian Smith, Eric Barnes, Kenneth McKay, and Mary Stewart, a member of the office staff from November 1942 to September 1943. He also interviewed Treweek in $1990 .{ }^{8}$ Some of that correspondence, together with the interview with Treweek, contains information of immense use to historians and cryptanalysts, and is also reproduced later in this volume.

6 Ibid., p. 3615.

7 Alan Stripp, 'Breaking Japanese Codes', Intelligence and National Security, vol. 2, no. 4, October 1987, pp. 135-50; and, Alan Stripp, Codebreaker in the Far East (London: Frank Cass \& Co, 1989), chapter 7.

8 It should be noted that, along with his unique insights, Treweek was surprisingly disparaging about two of his colleagues, mathematicians T.G. Room and R.J. Lyons. They were the two initial members of the army's Sydney University group, who had joined Nave's SIB in August 1941. Lyons returned to Sydney University in late 1942, but Room transferred to MacArthur's Central Bureau, where he headed the unit working on Japanese meteorological codes, which alerted the Allies to the targets of forthcoming Japanese air raids in 
In addition to those who had worked in the Special Section, Sissons corresponded with Steve Mason, a former sergeant who spent the war with the ASWG and who worked at the Mornington station from December 1945 until his discharge in October 1946. His accounts of the ASWG activities at Park Orchards, Bonegilla and Mornington, in letters to Sissons and me comprise a unique historical record (Annexes 8, 9).

He also began a systematic search in the US National Archives, where most of the Japanese diplomatic messages, known as Magic, that were intercepted throughout the war had been released for public access. In early 1986 he engaged a research assistant, Emma Craswell, to scour this archival material. He was excited to find a file entitled 'Copies of Messages Supplied by Australia with Clarifying Notes', dated 6 April 1943. He concluded to his absolute satisfaction that many of the Magic intercepts had originated at the Mornington station and been processed by D Special Section. Selections of his correspondence concerning his Magic searches in the United States are also reproduced later in this volume.

I joined Sissons in aspects of this quest in the mid-1980s. I interviewed Trendall in 1990 and Bond in 1994, and subsequently engaged in correspondence with them both. A letter from Bond to me is reproduced herein (Annex 10). It contains sketches of the layout of the Monterey Building in Queens Road and 'A' Block in Victoria Barracks, together with the names of the occupants of the particular rooms. (Note that Bond uses the British terminology of Ground Floor, First Floor and Second Floor in his diagrams, while most other accounts refer to the First, Second and Third floors).

In 1986 Sissons learned from Bond and Smith that, after the war and before the Section was disbanded, they together with Barnes had compiled a report on the Japanese diplomatic cyphers with which the unit had been engaged. (Over the next two decades, Sissons sometimes referred to this as 'the Barnes Report' or 'the Bond Report'). He immediately sought to locate a copy and request its declassification, as well as that of related material concerning the unit. At first, his efforts through the Defence Signals Directorate (DSD), the successor SIGINT organisation, were consistently stymied on the grounds that the material he wanted contained information that 'reveals details of an arrangement between Australian and foreign governments' and that 'the foreign governments concerned have not agreed to the public release of such information'. This was

the south-west Pacific area. The US secretary of the army stated in a letter to the vice-chancellor of Sydney University in September 1945 that Room had made 'a very valuable contribution ... to the Allied War Effort'. See Donovan and Mack, 'Sydney University, T.G. Room and Codebreaking in WWII', part 1; and, Donovan and Mack, 'Sydney University, T.G. Room and Codebreaking in WWII', part 2. 
a reference to the UKUSA Agreement, the postwar arrangements for SIGINT cooperation and exchange between the United States, the United Kingdom, Australia, Canada and New Zealand, and finally declassified in June 2010. ${ }^{9}$

Sissons, however, persisted with his efforts. Finally, after a decade of perseverance, in 1997, DSD released the 45-page report, entitled Report of Special Intelligence Section, HQ Australian Military Forces, Melbourne [on] Japanese Diplomatic Cyphers: Cryptographic Survey, produced in 1946 (NAA Series A6923/2, Item 1). The report was lightly edited by Sissons in 2006 with a view to publication. He wrote a 13,000-word introduction (not counting three pages of tables), covering the section's origins and history, and also appended a brief note on 'Sources'. He died before publication was secured, however, and his plan lapsed. The 1946 report, together with Sissons's introduction, comprises the main body of this volume.

Sissons continued to pursue aspects of the subject up until his death in October 2006. His later efforts were less concerned with reconstructing the organisation's history and more focussed on its cryptanalytic activities. As exemplified in his correspondence with McKay in late 2004, and with Bond in early 2005, he was particularly interested in the techniques and processes used by Trendall, Bond, Barnes, Smith and McKay to break specific Japanese diplomatic codes and cyphers, especially the FUJI and GEAM transposition cyphers. Three of his letters to McKay in November-December 2004 are reproduced herein (annexes 15, 17, 18). Sissons attached to his letter of 9 November 2004 an 11-page note describing his ongoing attempt to re-create the techniques that Trendall had used to break GEAM by encoding the famous Japanese 'Winds Set-up' messsage sent from Tokyo to the Japanese embassy in Washington on 19 November 1941 (Annex 16). He was stymied at the point where Trendall had invariably determined the correct sequence of the ten possible bigram columns used in the transposition blocks, and sought McKay's assistance.

Sadly, towards the end of his last letter in this collection, on 19 December 2004, he expresses his disappointment that he had been unable to uncover everything he had wanted about the Special Section's activities, and admits his eventual defeat in re-creating the techniques that Trendall had used with GEAM (Annex 18). He should not have been too distraught at his failure to match Trendall who, himself, was unable to explain how he did it. He told me in May 1990 that, although he was no mathematician, he had an inexplicable ability to see the patterns in the encoded text underneath the jumbled bigrams: 'You get a feeling for it. Your eye lights up on something, and ... bang' (Annex 2).

9 National Security Agency (NSA), ‘Declassified UKUSA Signals Intelligence Agreement Documents Available', 24 June 2010, at http://www.nsa.gov/public_info/press_room/2010/ukusa.shtml 


\section{Special Section}

D Special Section was a small but select organisation. A total of only 33 people worked in the section during the entire period from January 1942 to the end of the war. These consisted of eight 'technical' personnel, or 'code-breakers', plus another five lent by Central Bureau 'during heavy periods'; 11 'language and translation' personnel, plus two others 'lent by Central Bureau for short periods of heavy pressure'; and seven women typists and clerical assistants. In June 1943, it had ten members, comprised of three 'technical' personnel, four linguists/translators, and three typists and clerks. In July 1944, it had 17, comprised of six 'technical' personnel, five linguists/translators, and six typists and clerks. In August 1945, it had 18 members, comprised of six 'technical' personnel, plus one on loan, four linguists/translators plus two on loan, and five typists/clerks.

They were an illustrious group. The 'technical' members came from the worlds of Classics and Mathematics. They included Trendall, Professor of Greek and Archeology at Sydney University from 1939 to 1954, and then Deputy Vice-Chancellor and Master of University House at The Australian National University (ANU) until 1969; ${ }^{10}$ Treweek, later Professor of Classics at Sydney University; Ronald Bond, another Classics scholar who was later Vice-Principal of Scotch College for 18 years; McKay, who later became Reader in Classics at the ANU; Barnes, who later became Professor of Pure Mathematics and then Deputy Vice-Chancellor of the University of Adelaide; and Ian Smith, who was later Professor of Modern Languages at the University of Tasmania.

The linguists/translators included C. H. Archer and Hubert A. Graves from the British Consular Service, and Arthur R. V. Cooper from the FECB of the British Government GC\&CS. Archer had been the British Consul-General in Harbin, Manchuria. Cooper, brilliant and erratic, had worked at the FECB station in Hong Kong until late 1939 when, following Japan's invasion of China, the main body of the station was moved to Singapore. He was evacuated from Singapore by ship and submarine, together with his pet gibbon Tertius, and arrived at Monterey in March 1942. The gibbon was given to the Melbourne Zoo when Cooper returned to the United Kingdom in December 1942. Trendall said in May

10 Sissons lived in University House from when he arrived at ANU in 1961 until mid-1966. He was a fellow of the Governing Board and steward in 1964-66. From August 1965, when he and Bronwen were married, they lived in an apartment directly below Trendall's. They frequently dined with Trendall, on both formal and social occasions. Sissons later told me, however, that on no occasion did he and Trendall ever discuss their wartime service in D Special Section, nor even intimate that they were aware of the other's role. Trendall, of course, may not have known Sissons during the war, as he only returned to the section infrequently after June 1944, whereas Sissons only joined it in April 1945. Sissons would not have broached the subject. His natural shyness was a factor, but so was their age difference; Sissons thought himself too junior to the famous professor to share confidences. In any case, they were both men of discretion and respect for official secrecy. 
1990 that Cooper 'had a very fine brain' and that 'for intelligence purposes, [he] was very much at the top of the tree'. Sissons was one of the linguists/translators who was officially 'on loan' from Central Bureau.

D Special Section's role was to conduct crypanalytical activities with respect to intercepted Japanese diplomatic communications. The intercepts were obtained by monitoring Japan's worldwide network of HF radio stations used by the Foreign Ministry, including stations in Japan and stations in the Soviet Union, Germany, occupied China, French Indo-China, the Netherlands East Indies, and Thailand. The 52nd Australian Special Wireless Section was dedicated to intercepting this traffic, at Bonegilla until November 1943 and then Mornington until it was demobilised in late 1945. When reception of particular frequencies of interest was poor at Mornington, these were monitored by the ASWG stations at Darwin and Kalinga in Brisbane.

In addition, the Section received intercepts of Japanese diplomatic messages from the New Zealand army's Special Section located at Nairnville Park, Wellington, which extended coverage another 2,500 kilometres further east. ${ }^{11}$ Messages intercepted by the Special Section, as well as by the New Zealand navy's SIGINT organisation, were sent to FRUMEL on the daily commercial flights from Wellington. Much of the Nairnville Park material was forwarded to Central Bureau in Brisbane. Intercepted diplomatic traffic, such as FUJI and Type B Machine (PURPLE) material, was dispatched to D Special Section, where it was sorted according to whether it should be analysed by the Section or sent on to the Government Communications Bureau at Berkeley Street in London, the Diplomatic Section of GC\&CS.

The most lucrative source was the radio telegraphy circuit between Kuibyshev and Tokyo, via Irkutsk, which had the call sign RTZ. From October 1941 to around August 1943, from the German offensive intended to capture Moscow to the withdrawal of the German forces, much of the Soviet governmental apparatus, as well as the foreign legations, moved from Moscow to Kuibyshev, about 870 kilometres southeast of Moscow. It was also the primary circuit for communications between Moscow and Tokyo, relayed from Kuibyshev.

The Bonegilla station had begun 'highly successful' coverage of RTZ before February 1943. In early 1943 Bond instructed the station to watch the circuit carefully. In the six-month period from February to July 1943, the station intercepted 1,421 messages from Kuibyshev to Tokyo and 1,212 messages from Tokyo to Kuibyshev. RTZ accounted for 27 per cent of the messages from stations outside Japan intercepted at Mornington in May 1944. The New Zealand army's

11 Desmond Ball, Cliff Lord and Meredith Thatcher, Invaluable Service: The Secret History of New Zealand's Signals Intelligence During Two World Wars (Waimauku, New Zealand: Resource Books, 2011), pp. 202-04, 213. 
Special Section at Nairnville Park in Wellington maintained a special 24-hour watch for Japanese diplomatic communications on the RTZ link between Irkutsk and Tokyo. ${ }^{12}$

The cyphers analysed by the Section are the subject of the Cryptographic Survey produced in 1946. From its inception until July 1943, the Section's principal task was to decypher and process diplomatic messages sent in the high-grade FUJI transposition cypher, which was changed daily. The 1946 report notes that, by May 1942, 'virtually all traffic in the FUJI cypher [was] being read locally'. Trendall evidently 'devised an ingenious way of breaking the daily cypher so quickly and routinely that he could usually send the solution to London before work began there the next morning. ${ }^{13}$ The Section was the first Allied unit to break a transposition cypher introduced by the GEAM in July 1943. Soon afterwards, it broke the Foreign Ministry's BA transposition cypher.

The highest grade diplomatic encypherment system involved the HINOKI Machine Cypher (JAA, Type B, or PURPLE). The GC\&CS obtained a replica machine in early 1941, but none was available to D Special Section. It sorted the PURPLE intercepts from Mornington and Nairnville Park for forwarding to the Diplomatic Section of GC\&CS in London for decypherment. It also forwarded to London intercepts of messages from the Japanese military and naval attaches located with their overseas legations. By the end of 1943, the Section was sending about 800-900 attache messages to London per month.

\section{Intercepting Soviet radio traffic}

In 1994 Sissons told Horner that he believed D Special Section had had some involvement in cryptanalytical activities concerning Soviet radio traffic during the war. He explained this further in a letter to me in 1996 (Annex 11). He specifically recalled that Bond, who had succeeded Trendall as head of the Section in June 1944, had had a Russian intercept in his safe, which Sissons thought had probably predated his arrival in April 1945; and that members of the ASWG at the station near Darwin were intercepting Soviet diplomatic traffic around December 1945 and had been intercepting it 'during hostilities'. ${ }^{14}$

One former AWAS member, Margaret McBrien (later Griffin, as described by Steve Mason in Annex 8), told members of her family that she was engaged in interception of Russian traffic while she was at Mornington from September

12 Ball, Lord and Thatcher, Invaluable Service, pp. 202-13.

13 Merrillees, 'Professor A. D. Trendall and His Band of Classical Cryptographers', p. 14.

14 Ball and Horner, Breaking the Codes, p. 165. 
1944 to January 1946. She recalled traffic concerning Russian troop movements prior to their invasion of Manchuria and the northern Japanese islands during 9-20 August 1945.

By December 1945 the Mornington station was devoted almost entirely to Russian transmissions. Sergeant Steve Mason, who arrived at Mornington that month, has stated that: 'We took mostly Russian high speed traffic. On occasions, with the use of incentives, full logs were produced - I can remember one night's work which yielded more than 1000 messages'. The Russian intercepts were taken on Edison wax cylinders and transcribed later. They were taken each Wednesday to Victoria Barracks by a warrant officer, who passed them to the Diplomatic Section, now headed by Lieutenant Colonel Alastair ('Mic') Sandford, who occupied the same room as had Trendall and Bond (Annex 8).

D Special Section was only interested in the Japanese diplomatic traffic, at least until after Japan's surrender in August. It is likely, however, that at some point before December 1945, when the Mornington station was intercepting mostly Russian traffic, and prior to the ending of the war in August, it was intercepting both Japanese and Russian traffic, with D Special Section presumably passing the latter directly to London, along with some of the Japanese traffic.

\section{Detection of the Soviet espionage network in Australia}

It is likely that around this juncture the Mornington station and, incidentally, D Special Section, became involved in the beginnings of Australia's most serious espionage episode. On 6 January 1945, in a 'Top Secret and Personal' letter to the Acting Minister for the Army, General Sir Thomas Blamey, Commander-in-Chief of the Australian Military Forces (AMF) reported that, in the course of Allied intelligence operations, 'it has been definitely proved that there are leakages of information from Australia which have their origin apparently in Canberra'. Blamey gave four examples of intercepts of Japanese signals which contained details of Allied 'plans for certain operations in the Philippines' and details of recent Australian army intelligence estimates of Japanese strength there. The information came from Department of Information 'news background sheets' and AMF Weekly Intelligence Reviews prepared for War Cabinet and Advisory War Council meetings. The contents of an AMF Weekly Intelligence Summary issued on 4 November 1944 'were known in full' in Tokyo on 11 November. A file of material on which Blamey had based his letter was released in Canberra in July 1997. It contained details of eight instances of similar leaked information, sourced to the Soviet embassy in Canberra, during November-December 1944. For example, the details of Australian army deployments in New Guinea that 
were prepared for a meeting of the Advisory War Council on 16 November 1944, and circulated to members a few days beforehand, were in Japanese hands by 19 November. ${ }^{15}$

Neither Blamey's letter nor the supporting file identified the Allied agency that had discovered the leakages and thence informed Blamey about them. Neither does the material in the file specify the Japanese circuits monitored, or the relevant cypher used, or the station responsible for the intercepts.

Declassified files in the UK National Archives, however, indicate that the Allied agency which decyphered the Japanese traffic and alerted Blamey was the Diplomatic Section of GC\&CS in London. It is very likely that at least some of the messages were intercepted by the Mornington and Nairnville Park stations. Several of the messages originated in Harbin in Japanese-occupied Manchuria, and were sent to Tokyo by the Japanese Consulate in Harbin. Sissons thought it was possible that Mornington had intercepted these, which would then have been forwarded by D Special Section to London for decypherment. In addition, monitoring the RTZ circuit would have yielded important pieces of information about the leakages. For example, a telegram from Tokyo to Moscow on 13 May 1944, which said that the Japanese Consul-General in Harbin was receiving information from the Soviet Consul-General, was presumably transmitted on RTZ. In 1996, Sissons asked Craswell to search a series of recently released intercepts of telegrams between Harbin and Tokyo in the US National Archives for copies of either three particular messages mentioned by Blamey or any similar intercepts, but she found that intercepts for the dates of interest were still withheld from public access.

There is also the intriguing possibility that in early 1945 the Mornington station was tasked with monitoring Soviet traffic in the Far East in an attempt to discover any clues as to the process through which the leaked Australian secrets were being passed from Soviet to Japanese hands. Did the Japanese obtain them only in Harbin or also in Moscow or Kuibyshev, and in the case of Harbin, how were they transmitted from Moscow to Harbin for the handover? The stations at Mornington, Nairnville Park, Darwin and Kalinga were best suited for this search as they already monitored the airwaves across the relevant geographical area for GC\&CS's Diplomatic Section either on a dedicated basis or as radio reception conditions required. Sandford, the deputy head of Central Bureau, who was fully apprised of the matter from the beginning, took over D Special Section in late 1945 and was the personal recipient of the Soviet intercepts taken at Mornington. In February 1945 he noted, in connection with the investigation 
of the leakages, that 'the Russian Diplomatic traffic will still be required by the United Kingdom' and had asked that all such traffic should be sent to him at Central Bureau.

The subsequent US-UK cryptological operation known as Venona, in which large portions of Soviet intelligence communications between Moscow centre and its major overseas posts (such as London, Washington, New York and Canberra) for selected periods from 1943 to 1948 were decrypted, revealed the existence of a Soviet espionage network active in Australia, with at least ten members. It seems now clear that the office of Dr H. V. Evatt, the Attorney General and the Minister for External Affairs, in Martin Place in Sydney, was the source of the leakages concerning Allied war plans in 1944-45. The specific culprits were almost certainly Allan Dalziel, Evatt's private security (who was codenamed DENIS by the Soviet foreign intelligence service), and Ric Throssell (later codenamed FERRO). For example, it is most likely that Dalziel gave a Department of Information 'news background sheet' in November 1944 to Feodor Nosov (TEKHNIK), the Soviet Press Agency (TASS) representative (and senior Soviet intelligence officer) in Sydney. The information in this sheet was later found in practically identical terms' in an intercept of a Japanese message from Harbin to Tokyo. Nosov had immediately sent it to Moscow, from whence it was quickly sent to Harbin, somehow passed to the Japanese Consulate and then sent to Tokyo. Stalin was engaged in the higher statecraft of prolonging the fighting in the southwest Pacific theatre for as long as possible, or at least until Soviet forces could be moved from the western front to enter the war against Japan and enable Moscow to join in the peace negotiations, for which the eventual prize was Sakhalin Island and the Japanese 'Northern Territories' ${ }^{16}$

There remain important unanswered questions concerning this opening phase of the espionage case. Some answers could well be derived from the files of GC\&CS's Diplomatic Section and US Magic records that are still classified. Sissons's painstaking research and analysis of the activities of the Mornington station and the possible role of D Special Section in the handling of Soviet intercepts, however, uncovered enough to keep the door slightly ajar for eventual discoveries.

\section{The Kormoran cryptogram and the sinking of HMAS Sydney}

In his essay in 2006 on D Special Section's origins and history, Sissons revealed that the Section had successfully decyphered a German account of the sinking

16 Ball and Horner, Breaking the Codes, pp. $\mathrm{xx}$, 343; and, Ball, 'The Moles'. 
of HMAS Sydney by the Kormoran, a German auxiliary cruiser or 'raider', off the coast of Western Australia near Carnarvon, on 19 November 1941. How a modified merchant ship could sink a Leander-class cruiser, with the loss of all 645 men aboard, has never been satisfactorily explained. Sissons's essay, however, casts new light on this controversial incident.

Sissons recalls that on 11 January 1945, a group of about 20 survivors from the Kormoran, including Commander Theodor Detmers, the ship's captain, attempted to escape from a POW camp in Victoria. While a prisoner, Detmers wrote an encoded account of the battle, which was found on him when he was recaptured a week after the breakout. The cryptogram, which consisted of about 6,250 characters, was given to D Special Section to decypher. Smith, who was fluent in German, played the main role in its solution, assisted by Barnes on the mathematical side. (It should be noted, however, that Treweek told Sissons in October 1990 that it had been solved by Keith Miller, who is not listed as a member of D Special Section in the 1946 account, but had previously worked under Nave in the Special Intelligence Bureau). It involved a relatively simple form of 'polyalphabetic substitution' cypher; Sissons shows, through a six-page reconstruction, how it was soon decyphered. It evidently consisted of the deck and engine room logs from the sighting of the Sydney until the scuttling of the Kormoran some eight and a half hours later and, Sissons notes, provides 'the most reliable account of how Sydney met her fate'. It shows that, 'before verifying the raider's identity, Sydney approached to within point blank range and was crippled by fire from Kormoran's main and secondary armament before she could bring fire to bear'.

\section{The Sissons legacy}

Sissons served in D Special Section for only five months. It is only because of his extraordinary efforts, however, that the Section's story could be reconstructed and published. It is very likely that the 1946 cryptographic report would have remained unreleased and unknown, were it not for his persistence, fuelled by his knowledge of its existence. He initiated and pursued most of the correspondence with former members of the Section, and arranged key interviews, putting together a detailed account of its origins and history that would otherwise have not been recorded. He was assiduous and indefatigable. He is owed a great debt by scholars and practitioners concerned with the science of cryptography as well as historians of the cryptological aspects of the war in the Pacific. 


\section{Withdrawal of the 1946 report}

In late 2012, when we were checking the archival sources cited by Sissons, we learned that the Report of Special Intelligence Section, HQ Australian Military Forces, Melbourne [on] Japanese Diplomatic Cyphers: Cryptographic Survey (1946) had been withdrawn from public access on 2 June 2011. After 14 years of public viewing and copying as NAA Series A6923/3, Item 1, the report is now officially 'withheld pending access advice from an agency/agencies'. Sissons would not have been surprised at the redaction; he would have smiled, commented wryly on the ludicrousness of the decision, and continued doggedly with his efforts to secure public appreciation of the activities of the Special Section.

We also found that the associated items in Series A6923/3 had recently been either recatalogued or removed from access. (We have retained Sissons's NAA references in his footnotes, however; they were undoubtedly correct during his last visits to the NAA in 2004-06). Sissons would have regarded all this as just another tiresome challenge for investigative scholars. 